ИГУМНОВ Евгений Владимирович - кандидат исторических наук, доцент кафедры организации, экономики и управления ветеринарным делом, Санкт-Петербургская государственная академия ветеринарной медицины (196084, Россия, Санкт-Петербург, ул. Черниговская, 5; eiguтnоv@list.ru)

\title{
СЕКРЕТАРИ СИБИРСКИХ СТАТИСТИЧЕСКИХ КОМИТЕТОВ - ЧИНОВНИКИ, УЧЕНЫЕ И ОБЩЕСТВЕННЫЕ ДЕЯТЕЛИ
}

Аннотация. В статье на примере Сибири рассматриваются обязанности, научная и общественная деятельность делопроизводителей - секретарей губернских и областных статистических комитетов в XIX начале XX в. Автор отмечает, что им принадлежало особое место в системе краевого бюрократического аппарата Российской империи.

Ключевые слова: чиновничество, статистические комитеты, секретари, наука, краеведение, Российская империя

И стория чиновничества - одна из наиболее актуальных тем в отечественной историографии. Многие исследователи отмечают значительную роль чиновничества в системе государственного управления Российской империи, его влияние на развитие страны [Зайончковский 1978; Матханова 1998; Оболонский 2011]. Внимание к данной теме подогревается противоречивостью восприятия чиновника-бюрократа в художественной и научной литературе, общественном мнении. «Представление о прошлом России, - писал в начале XX в. М.С. Александров (Ольминский), - покоится на учении о трех китах: закрепощении всех сословий государством, господстве бюрократии, абсолютизме» [Александров 1910: 4]. Под бюрократией М.С. Александров понимал правящую группу лиц, объединенных чинопроизводством. Российских чиновников XIX в. часто наделяют такими эмоционально-экспрессивными образами, имеющими негативный оттенок, как «чинодралы», «формалисты», «мздоимцы» и т.д. При этом чем дальше от столичных городов, тем более критичным, и не без причины, становилось отношение к чиновничеству. Согласно цифрам, полученным восточносибирской администрацией в первой половине 1870-х гг, на Иркутскую губернию приходилось 246 тыс. руб. «темных поборов» в год, на Енисейскую - 178, на Забайкальскую область - 231 и на Якутскую область 22 тыс. руб. [Суворов 1894: 219]. Неблагоприятная характеристика чиновников подкрепляется воспоминаниями современников о жизни в Сибири. «Конечно, в те времена, - рассуждал по поводу распространившейся к середине XIX в. практике взяточничества и чиновничьего самоуправства генерал от инфантерии И.Ф. Бабков, - при огромной массе чиновников, административной централизации, господстве сухого и мертвящего формализма, отсутствии руководящих начал к укреплению в обществе чувства законности и вообще при совокупности многих других неблагоприятных обстоятельств, укоренившихся в существовавшем строе нашей государственной и общественной жизни, было затруднительно искоренить это зло» [Бабков 1912: 50]. «Вообще в Сибири состав служащих, - дополняет нелицеприятную картину бывший тобольский губернатор В.А. Тройницкий, - был невысокого уровня, и не только из местных уроженцев, но в особенности из приезжих. В Сибирь большею частью ехали на службу неудачники по службе или вынужденные уехать по семейным неладам, или спасаясь от долгов. К тому же содержание служащих по министерству внутренних дел ничтожное, и мало находилось охотников ехать на 
службу в Сибирь. Приходилось обходиться теми людьми, которые находились на местах» [Тройницкий 1913: 538]. Тем не менее сегодня отмечается, что чиновничье сословие по своему составу, происхождению, уровню образования и материального достатка было неоднородным и менялось с течением времени. Среди чиновников было немало достойных лиц, верой и правдой служивших государству, стремившихся улучшить жизнь общества и оставивших заметный след в истории Сибири [Дамешек 2013; Карчаева 2016].

Цель статьи - определить место секретарей статистических комитетов в структуре губернского административного аппарата, рассмотреть их научную и общественную деятельность.

В первой четверти XIX в. в России, как и в других европейских странах, началось формирование статистической службы. Вступление в новую стадию модернизации вызвало необходимость в получении более точных данных о состоянии и тенденциях развития общества. По мнению американского историка Дона К. Роуни, статистика, сформировавшаяся как научная дисциплина в XVIII-XIX вв., позволяла обеспечить российские власти «мощными средствами для более тщательного надзора за торговлей и промышленностью, сельским хозяйством, облагаемыми налогом ресурсами, быстро меняющимся населением империи и самим государственным управлением» [Rowney 2009: 36]. В 1811 г. в процессе реорганизации министерской системы при Министерстве полиции было образовано Статистическое отделение, в задачи которого входили: подготовка плана устройства статистической части, усовершенствование губернаторских отчетов, обработка предоставляемых губернаторами данных и составление сводных отчетов. В 1819 г. Статистическое отделение перешло в ведение Министерства внутренних дел (МВД), в 1823 г. было включено в состав Департамента полиции исполнительной [Елисеева, Дмитриев 2013: 15]. Утвержденные в декабре 1834 г. императором Николаем I «Правила для Статистического Отделения при Совете Министерства Внутренних Дел и Статистических Комитетов в Губерниях» послужили правовым базисом для устройства многоуровневой системы государственной статистики. Ее ведущим звеном на губернском уровне провозглашались статистические комитеты, напрямую вплетенные в краевой бюрократический аппарат. В зависимости от особенностей организации региональной власти комитеты состояли под председательством гражданских губернаторов и главным ведением (там, где имелись) генерал-губернаторов. Основными официальными каналами для получения сведений служили материалы, поступавшие через непременных членов: вице-губернатора, попечителя гимназии, прокурора, инспектора врачебной управы, члена духовной консистории и др. Один из членов комитета назначался его делопроизводителем ${ }^{1}$. Окончательно функции, состав и финансирование статистических комитетов были определены в 1850-1860-х гг. В соответствии с Положением 1860 г. их первоочередной обязанностью объявлялось составление статистических таблиц, установленных Центральным статистическим комитетом (ЦСК), ведомостей, прилагаемых к всеподданнейшим отчетам начальников губерний, и списков, необходимых при раскладке на каждое трехлетие земских повинностей ${ }^{2}$.

В 1835-1836 гг. статистические комитеты были образованы в Томске, Иркутске, Енисейске, Омске, Тобольске, во второй половине XIX в. - в Чите, Якутске, Семипалатинске, Владивостоке, Благовещенске. Постепенно с рефор-

\footnotetext{
${ }^{1}$ Полное собрание законов Российской империи. Собрание II (ПСЗРИ-2). Т. ХІ. Отд. II. 1834. № 7684. C. 280-283.

2 ПСЗРИ-2. Т. XXXV. Отд. II. 1860. № 36453. С. 504-511.
} 
мированием статистической службы определились требования к кандидатуре и объем полномочий делопроизводителя - секретаря комитета. Согласно Правилам 1834 г. денежные средства статистическим комитетам не выделялись, жалованье делопроизводителям не полагалось. Как итог, делопроизводители не задерживались на своем месте, и в 1840-х гг. большинство сибирских статистических комитетов приостановили работу. В этих условиях особенно важным явилось утверждение в соответствии с Положением 1860 г. постоянной должности секретаря и ежегодного финансирования комитетов. В 1865 г. отдельным законодательным актом Положение 1860 г. было распространено на Сибирь. Именно во многом благодаря принятию данного Положения и введению штатной должности секретаря работа сибирских комитетов приобрела последовательный, непрерывный характер.

В обязанности секретаря входило осуществление контроля над сбором, систематизацией, обработкой и поверкой срочных статистических данных, координирование местных статистических исследований и научных занятий членов комитета, ведение переписки и денежной отчетности. В Положении оговаривалось, что секретарь статистического комитета должен был назначаться начальником губернии преимущественно из лиц, получивших ученую степень или окончивших полный курс наук в высших учебных заведениях, что, с одной стороны, обеспечивало необходимый уровень функционирования учреждения, а с другой - высокие требования создавали дополнительные сложности при выборе кандидатуры на должность секретаря. Прежде всего это касалось деятельности провинциальных статистических комитетов [Лебедев 2010]. Вплоть до начала XX в. основная часть представителей сибирского чиновничества имела начальное и среднее образование. В связи с этим допускался прием на должность секретаря лиц со средним или неполным высшим образованием. При вступлении в должность секретарю присваивались права службы, сопоставимые со статусом правителей канцелярий гражданских губернаторов и старших секретарей губернских правлений: VIII класс по чинопроизводству, VIII разряд по шитью мундира и по пенсии, назначался оклад жалованья в размере 750 руб. Разрешалось, если это не отражалось на основных обязанностях, совмещать должность секретаря с работой в административных и образовательных учреждениях, а также в качестве редактора губернских и областных ведомостей. Чиновникам, выслужившим полную или половинную пенсию по учебной части либо в каком-либо другом ведомстве, сохранялась пенсия сверх жалованья. Для многих работа в статистическом комитете давала возможность повысить свой статус в системе государственной службы и улучшить личное материальное положение, для администрации закрыть кадровый вопрос. В любом случае, приоритет, как правило, отдавался кандидатурам, хорошо знакомым с краем и проявлявшим интерес к исследовательской деятельности.

Научная работа относилась к числу так называемых необязательных занятий статистических комитетов, призванных обеспечить исправное содержание местной административной статистики. Положением 1860 г. были обозначены основные задачи исследовательской деятельности комитетов. Им предоставлялось право заниматься подробным описанием губернии, области в топографическом, этнографическом, историческом, сельскохозяйственном, торговом и промышленном отношениях. На практике направленность исследовательской деятельности сибирских комитетов зависела от целого ряда факторов: состава непременных и действительных членов, правительственных распоряжений, информации, запрашиваемой ЦСК, региональными и центральными органами власти, контактов с научными учреждениями, интересов, степени активности 
и организаторских способностей секретарей комитетов. В сфере их внимания находились вопросы улучшения производительности сельского хозяйства, рыболовства и звероводства, горной промышленности, развития транспортного сообщения, земледельческой колонизации и т.д. Большая роль отводилась изучению культуры и быта, исторического прошлого населения Сибири. Результаты исследований печатались на страницах «Трудов» и «Памятных книжек» статистических комитетов, изданий краевых научных обществ, в периодической печати.

В разные годы секретарями статистических комитетов являлись известные в Сибири и России ученые и краеведы Г.Н. Потанин, Н.А. Костров, А.В. Адрианов (все - Томский комитет), И.Я. Словцов (Акмолинский комитет), Н.Я. Коншин (Семипалатинский комитет), А.И. Попов (Якутский комитет), А.В. Кириллов (Амурский комитет) и др. Некоторые из них посвятили работе в комитетах значительную часть своей жизни. С 1868 по 1884 г. должность секретаря Иркутского комитета занимал Д.Д. Ларионов. За это время им изданы статьи «Табачная производительность», «Записка о церквах и башнях заштатного г. Илимска», «Цифры инородческого населения Иркутской губернии и несколько заметок о их настоящем положении», книги «Очерк экономической статистики Иркутской губернии. Статистика сельскохозяйственная», «Губернский город Иркутск (Пожары 22-го и 24-го июня 1879 г.)» и др., проведены 3 городские переписи населения (1875, 1879, 1884 гг.). Почти 30 лет, с 1879 по 1908 г. с небольшими перерывами, Якутский комитет возглавлял А.И. Попов. При его содействии в 1894-1896 гг. проведена Якутская экспедиция Восточно-Сибирского отдела Императорского Русского географического общества (ВСО ИРГО), в 1886 г. организованы метеорологические наблюдения в Якутске [Винокуров 2001: 6]. 15 лет отдал службе на посту секретаря Томского статистического комитета Н.А. Костров. Н.А. Костров родился в 1823 г. в Орловской губернии. В 1846 г., вскоре после окончания Московского университета, перевелся из Московской губернии в Красноярск, где получил должность чиновника по особым поручениям при енисейском губернаторе. В 1852-1855 гг. исполнял обязанности делопроизводителя Енисейского статистического комитета. В 1866 г., после переезда в Томск, назначен на должность секретаря Томского статистического комитета, в которой состоял до 1881 г. Н.А. Костров - автор более 150 статей по географии, статистике и этнографии Сибири. Научная деятельность Н.А. Кострова отмечена малой золотой медалью ИРГО и серебряной медалью Общества любителей естествознания, антропологии и этнографии [Шевцов 2011: 95].

В течение XIX - начала XX в. быстро растет число сибиряков, вовлеченныХ в общественную и краеведческую деятельность. Заметный вклад в становление статистической службы и изучение Сибири внесли уроженцы Тобольской губернии И.Н. Юшков, К.М. Голодников, А.В. Адрианов. И.Н. Юшков, секретарь Тобольского комитета в 1869-1870-е гг., родился в 1833 г. в Тобольске в семье священника Софийского кафедрального собора. И.Н. Юшкову принадлежат статьи о сибирских татарах, развитии торговли и промышленности в Западной Сибири. К.М. Голодников, секретарь Тобольского комитета в 1880-е гг., стоял у истоков его основания. Первые упоминания об участии К.М. Голодникова в работе комитета относятся к 1840-м гг. Он интересовался вопросами экономики, географии и истории Тобольской губернии. А.В. Адрианов - секретарь Томского статистического комитета в 1887-1888 гг. В 1879 г. он входил в состав экспедиции Г.Н. Потанина в Северо-Западную Монголию, в 1880 г. награжден малой серебряной медалью, в 1883 г. - малой золотой медалью ИРГО. Как секретарь Томского статистического комитета совершил несколько поездок 
на р. Васюган и в Нарымский край, по итогам которых собрал обширную коллекцию предметов материальной культуры остяков и самоедов, написал труд «Кетские инородцы» [Васенькин 1998: 34]. Также сибирское происхождение имели секретари Томского, Иркутского и Якутского комитетов Г.Н. Потанин, Н.М. Павлинов и А.И. Попов.

Большие возможности, которые открывала должность секретаря, способствовали привлечению в статистические комитеты людей с активной общественной позицией. К 1860-м гг. относится возникновение сибирского областничества - общественно-политического течения, сформировавшегося под влиянием идей революционно-демократического движения в России, западных теорий о колониализме и направленного на отстаивание интересов и поиск путей развития Сибирского региона. В 1865 г. в Томском комитете в течение нескольких месяцев, до ареста, работал один из основоположников сибирского областничества, ученый и общественный деятель Г.Н. Потанин [Скопа 2011]. В конце 1850-х - начале 1860-х гг. в круг сибирских студентов С.-Петербурга, ставивших целью выработать общее видение относительно будущего Сибири, вместе с Г.Н. Потаниным входил Н.М. Павлинов. Получив образование, он уехал в Иркутск и до 1867 г. возглавлял Иркутский статистический комитет. Продолжателем идей областничества являлся секретарь Томского комитета А.В. Адрианов [Дэвлет 2002: 12].

Высшая сибирская администрация, несмотря на правовые ограничения, широко использовала силы, знания и способности политически неблагонадежных лиц, позволяя им заниматься наукой, оказанием юридической и врачебной помощи населению [Сальникова 2017: 71]. Во второй половине XIX в. секретарями сибирских комитетов работали Е.П. Михаэлис, Н.Я. Коншин, Л.Е. Луговский, П.Е. Кулаков. Е.П. Михаэлис был сослан в г. Тару Тобольской губернии из-за участия в студенческих волнениях 1861 г. в СанктПетербургском университете. В 1869 г. он получил разрешение поселиться в Семипалатинске, в 1878 г. был назначен секретарем только что образованного областного статистического комитета. Занимался геологическими исследованиями, изучением животного мира, археологией, этнографией казахского народа. В середине 1890-х гг. на должность секретаря Семипалатинского комитета был приглашен бывший политический ссыльный Н.Я. Коншин. В сферу его интересов входило исследование исторического прошлого, культуры и быта народов Семипалатинской области. Он также сыграл видную роль в учреждении Семипалатинского подотдела ЗСО ИРГО [Буктугутова 2007: 86], избирался городским головой Семипалатинска, в 1906-1907 гг. депутатом Государственной думы I и II созыва. Л.Е. Луговской, секретарь Тобольского статистического комитета в 1897 г., был сослан в Тобольск в 1882 г. за устройство динамитной мастерской. В 1889 г. он получил право поступить на государственную службу. Принимал участие в работе Тобольского губернского музея, в 1890-е гг. был редактором неофициальной части «Тобольских губернских ведомостей». П.Е. Кулаков, возглавлявший в 1897 г. Енисейский комитет, был сослан в Иркутскую губернию в 1890 г. В 1897 г. под его руководством статистический комитет организовал научную экспедицию по изучению хозяйственного быта инородцев Минусинского и Ачинского округов [Хорина 2012: 33].

Отдельным направлением «необязательных» занятий статистических комитетов являлось накопление коллекций по разным отраслям знаний, устройство краевых музеев, имевших огромное общеобразовательное, культурное и научное значение. Работа по созданию музеев при статистических комитетах во многом строилась вокруг секретарей и их умения объединить вокруг себя 
общественность. В 1870 г., благодаря коллекциям, пожертвованным секретарем И.Н. Юшковым, было положено начало формированию музея Тобольского статистического комитета, получившего в конце 1880-х гг. статус губернского. В 1891 г. музей взял под свое покровительство тогда еще наследник российского престола Николай II. Создание музея при Семипалатинском комитете (открыт 11 сентября 1883 г.) связывается с именем Е.П. Михаэлиса. Найденные им во время раскопок древних курганов предметы легли в основу археологической коллекции музея [Хотимский 2007: 12]. В 1891 г. по инициативе А.И. Попова был учрежден музей Якутского статистического комитета.

Секретари комитетов поддерживали тесные отношения с научными обществами и другими негосударственными организациями, органами городского самоуправления. А.В. Кириллов, будучи секретарем Амурского статистического комитета (1895-1899 гг.), состоял гласным Благовещенской городской думы, в 1898 г. был избран городским головой. Он уделял значительное внимание положению переселенцев. В 1896 г. по его инициативе в Благовещенске было образовано Общество вспомоществования нуждающимся переселенцам. Гласным Якутской городской думы избирался секретарь Якутского комитета А.И. Попов. С его деятельностью в Якутске связываются строительство зданий реального училища, казначейства, Ольгинского приюта, организация Вольного пожарного общества, электрификация города и т.д. [Ефремов 2017: 92].

Таким образом, в течение XIX - начала XX в. в Сибири сформировалась система региональных статистических учреждений. Не ограничиваясь решением только одних государственно-административных задач, статистические комитеты вели большую исследовательскую работу, способствовали становлению музейного дела. По мнению Г.П. Пирожкова, комитеты были «первыми государственными учреждениями, включившимися в краеведческую деятельность» [Пирожков 2012: 177]. Ведущую роль в координировании статистической и научной работы, консолидации краеведческих сил играли секретари комитетов. Для части из них переход на должность секретаря являлся продолжением их общественной деятельности, представлял собой возможность сосредоточиться на занятиях наукой. Все вышеизложенное позволяет говорить о том, что секретарям комитетов принадлежало особое место в системе краевого бюрократического аппарата Российской империи.

\section{Список литературы}

Александров М. 1910. Государство, бюрократия и абсолютизм в истории России. СПб: Типография Б.М. Вольфа. 176 с.

Бабков И.Ф. 1912. Воспоминания о моей службе в Западной Сибири. 18591875 г. СПб: Типография В.Ф. Киршбаума. 576 с.

Буктугутова Р.С. 2007. Роль Западно-Сибирского отдела Русского географического общества в развитии культурных связей русского и казахского народов (конец XIX - начало XX в.). - Вестник Томского государственного университета. Сер. История. № 296. С. 84-88.

Васенькин Н.В. 1998. Вступительная статья к публикации писем А.В. Адрианова к Г.Н. Потанину. - Вестник Томского государственного университета. T. 266. № 1: Гуманит. спец. вып. С. 33-35.

Винокуров П.В. 2001. О потомственном казаке Попове. - Илин. № 1(24). C. 6-9.

Дамешек И.Л. 2013. Чиновничество как «высший класс» сибирского общества: численность, уровень образования, материальное положение, влияние на общественную жизнь. - Известия Иркутского государственного университета. Сер. История. № 1. С. 48-55. 
Дэвлет М.А. 2002. А.В. Адрианов как этнограф. - Репрессированные этнографы. Вып. І. М.: Восточная литература. С. 9-56.

Елисеева И.И., Дмитриев А.Л. 2013. История российской государственной статистики: 1811-2011. М.: ИИЦ «Статистика России». $143 \mathrm{c.}$

Ефремов А.Н. 2017. Руководящий состав Якутской городской думы (18561917 гг.). - Вестник Северо-Восточного федерального университета им. М.К. Аммосова. Сер. История. Политология. Право. № 4(8). С. 85-95.

Зайончковский П.А. 1978. Правительственный аппарат самодержавной России в ХІХ в. М.: Мысль. 288 с.

Карчаева Т.Г. 2016. Социокультурный портрет чиновников Енисейской губернии (1822-1917 гг.). - Гуманитарные науки и образование. № 1(25). С. 135-139.

Лебедев С.В. 2010. Роль секретаря губернского статистического комитета в организации научных исследований Астраханского края. - Астраханские краеведческие чтения: сборник статей. Вып. II. Астрахань: Издательство Сорокин Роман Васильевич. С. 181-188.

Матханова Н.П. 1998. Генерал-губернаторы Восточной Сибири середины ХІХ века: В.Я. Руперт, Н.Н. Муравьев-Амурский, М.С. Корсаков. Новосибирск: Изд-во СО РАН. 428 с.

Оболонский А.В. 2011. Кризис бюрократического государства: Реформы государственной службы: международный опыт и российские реалии. М.: Фонд «Либеральная миссия». 448 с.

Пирожков Г.П. 2012. Российское родино(крае)ведение: зарождение и развитие (вторая половина XIX - начало XX в.). - Исторические, философские, политические и юридические науки, культурология и искусствоведение. Вопросы теории и практики. № 2-2. С. 175-182.

Сальникова Е.С. 2017. Положение уголовных и политических ссыльных в Сибири во второй половине XIX века. Сравнительный анализ. - Известия лаборатории древних технологий. Т. 13. № 1(22). С. 67-74.

Скопа В.А. 2011. Одна из страниц деятельности Г.Н. Потанина-статистика. Вестник Томского государственного университета. Сер. История. № 2. С. 42-43.

Суворов П. 1894. Сенатор Н.П. Синельников (биографический очерк). Исторический вестник. T. LVI. Апрель. С. 203-220.

Тройницкий В. 1913. Неурожай в Тобольской губернии 1891 года. Исторический вестник. Т. СХХХІІІ. Август. С. 536-552.

Хорина В.В. 2012. Енисейский губернский статистический комитет: к истории создания и деятельности. - Вестник Томского государственного педагогического университета. № 9(124). С. 29-35.

Хотимский Ю. 2007. Евгений Петрович Михаэлис. - Михаэлис Евгений Петрович. 1841-1913. Краеведы Восточного Казахстана. Усть-Каменогорск: КГП «Областная газета "Рудный Алтай”». С. 9-25 .

Шевцов В.В. 2011. Николай Алексеевич Костров - автор неофициальной части «Томских губернских ведомостей» в 1866-1881 гг. - Журналистика провинции: альманах. Вып. 7. Ставрополь: Изд-во Ставропольского гос. ун-та. C. $90-100$.

Rowney D.K. 2009. Imperial Russian Officialdom during Modernization. - Russian Bureaucracy and the State: Officialdom from Alexander III to Vladimir Putin (ed. by D.K. Rowney, E. Huskey). Basingstoke, England: Palgrave Macmillan. P. 26-45. 
IGUMNOV Evgeniy Vladimirovich, Cand.Sci. (Hist.), Associate Professor of the Chair of Veterinary Organizations, Economies and Management, Saint Petersburg State Academy of Veterinary Medicine (5 Chernigovskaya St, St.Petersburg, Russia, 196084; eigumnov@list.ru)

\title{
SECRETARIES OF THE SIBERIAN STATISTICAL COMMITTEES: OFFICIALS, SCIENTISTS AND PUBLIC FIGURES
}

\begin{abstract}
On the example of Siberia, the article presents the activity of clerks - secretaries of provincial and regional statistical committees in the $19^{\text {th }}$ - early $20^{\text {th }}$ centuries. The article reveals the transformation of the material situation, rights and duties of the secretaries of committees, and shows their contribution to the study of the Siberian region, organization of regional museums, interaction with scientific societies, city government bodies. At the same time, it states that scientific work was one of the so-called non-compulsory occupations of statistical committees, designed to ensure the correct maintenance of administrative statistics. In the second half of the $19^{\text {th }}$ century top Siberian administration, despite legal restrictions, widely used the forces, knowledge and abilities of politically unreliable persons, allowing them to be occupied with science, provide legal and medical assistance to the population. The author notes that the secretaries of the committees had a special place in the system of the regional bureaucratic apparatus of the Russian Empire.
\end{abstract}

Keywords: officialdom, statistical committees, secretaries, science, local lore, Russian Empire 